\title{
Identification and Ranking the Most Significant Risks of the Mega Construction Projects in Saudi Arabia
}

\author{
Abdulmoneim $\mathrm{AM}^{1^{*}}$, Al Samadony A², Nosair IA ${ }^{3}$ \\ ${ }^{1}$ Bachelor Degree in Civil Engineering 2004, Alexandrea University, Egypt \\ ${ }^{2}$ Professor of Construction Management, Faculty of Engineering, Helwan University, Egypt \\ ${ }^{3}$ Professor of Construction Management, Faculty of Engineering, Ain Shams University, Egypt
}

DOI: $10.36348 /$ sjce.2021.v05i02.003

| Received: 24.02.2021 | Accepted: 14.03.2021 | Published: 16.03.2021

*Corresponding author: Abdulmoneim AM

\section{Abstract}

Megaprojects are a large-scale project with an expensive cost and long time schedule, this unique kind of projects are usually given their infamous reputation as it is often result in undesired outcomes same as enormous cost overruns and time extensions. In a lot of cases of undesired outcomes, we can predict that it is due to not managing megaprojects characteristics as skillfully as required and wrong combination of that characteristics which lead to a disaster. Improper managing the different managerial aspects of mega projects is reflecting a failure in the achievement of the project requirements especially in case of risk managements where we can say that, Mega projects is resulting a Mega risk. Risk management is currently considered to be a mandatory part of project management in general and an integral part of successful project management while the main aspect which is projects management is different from megaprojects than in other types of projects (small- and medium-scale projects) as in case of megaproject the management is more complex and complicated due to the size and complexity of that kind of projects. In this research the author studied the Risk Management in the Mega construction projects in the kingdom of Saudi Arabia (KSA) and the main objective of this research was to apply the best ways of managing the risk in case of mega construction projects starting from identifying the most significant risks which impact this kind of project in KSA and then analyze the identified risk qualitatively to determine its impact in the project objective and to find out the most significant 15 risks after the ranking of the identified risk depending on the risk importance index of every risk the research resulted in identifying 57 risks and categorize those risks in 2 main groups and 8 subgroups one of them is related the mega construction projects characteristics and then the most important risks has been determined.

Key words: Mega Project, Risk Management, KSA, Risk Identification, Risk Analysis, Risk Ranking, Qualitative analysis, Construction Industries.

Copyright (C) 2021 The Author(s): This is an open-access article distributed under the terms of the Creative Commons Attribution 4.0 International License (CC BY-NC 4.0) which permits unrestricted use, distribution, and reproduction in any medium for non-commercial use provided the original author and source are credited.

\section{INTRODUCTION}

The construction industry is one of the engines of economic growth in the world. It is considered one of the main sources of income for countries and individuals alike. It is creating a job opportunity for many professional groups, especially engineering ones, but today it faces challenges due to many factors, the financial and economic crisis, the politic circumstances, postponed or even cancelled investments, rising unemployment, High global prices...etc. These factors have a negative impact on the economy as well as on the construction industry and lead to change the clients and construction companies' behavior its desire to compete and break into this kind of industries.
It is generally accepted that the construction industry of any country has a significant positive impact on the national economy of that country. As per the 2018 report of the United Nations Economic Commission for Europe (UNECE), the contribution of the construction sector in GDP terms was $10.4 \%$ and in the Kingdom of Saudi Arabia (KSA) the construction sector is growing, and it represents around 6\% of total Saudi Arabia's gross domestic product (GDP) according to same report.

Although there is still a positive impact in GDP growth in KSA due to the construction industry, but the kingdom is facing a significant problem related to the same sector of industry especially in the case of 
mega projects. From the construction management point of view we can say that a main part of this troubles are related to the lack of risk management and proper analysis to the potential impact of that risks, according to the [3], the cost of top 10 Saudi Arabia's mega projects $\$ 92$ billion, those projects was including the projects of the two holly Harams Makkah and Madinah with a cost of $24 \$$ billion and completion date at mid of 2019, Kingdom Tower, located in Jeddah which costed $1.8 \$$ billion and planned to be completed at March 2020, Abraj Kudai in Makkah with 3.5\$ billion with a planned completion date at the end of 2017 , Riyadh Metro project with a cost of $24.4 \$$ billion with a planned completion date at December 2020, Mall of Saudi by Majid Al Futtaim Group, and new Oil \& Gas Processing Facility, the Jazan Oil Refinery located in Jazan Economic, most of those projects ongoing or stopped at all while the closing of those project as per every project plan was from 2017 to 2020 . This delay in the construction project in KSA has a chronic delay history, according to Assaf and Al-Hejji [1], 70\% of public projects was delayed in Saudi Arabia. And also according to M. Alzara, J. Kashiwagi, D. Kashiwagi and A. Al-Tassanin 1983, Zain Al-Abedien reported that $70 \%$ of projects were delayed when the Ministry of Housing and Public Works was responsible for them.

Due to all the above and because of this new construction boom in KSA specially in the mega project in the recent period, the importance of studying the impact of risks on Saudi Arabia construction industry in general and on mega-projects has emerged, as it was found that many mega-projects had been suspended for an indefinite period or closed entirely at different stages of the project life cycle, resulting in heavy losses to contracting companies and sponsors alike.

\section{Problem Statement}

Mega projects are characterized by characteristics that make them different in their management from Regular projects, that they are projects of a high degree of complexity as they have a high cost which exceeds billions of Dollars, and their execution period may exceed five years [2]. It impedes its success as mega projects are also exposed to mega risks.

Therefore, the factors that lead to the occurrence of risks in mega projects have become so important that they must be carefully studied, defined, and analyzed so that they are dealt with in a way that reduces their impact, if they occur.

The impact of risk in the construction project objective is directly or indirectly impacting the project time and then it is impacting the project cost as well, so that the research studied the impact of the risks in the project objectives.
In the last 10 years it was a boom in the public projects in KSA some of that project in this period of time classified as megaproject with more than $1 \$$ billion, most of that mega projects either stopped or delayed or troubled. The problem which faced those projects and was having a severe impact in those projects stability is reflecting a lack of risk study and management. Also when we check and find some mega projects like the two holly Harams Makkah and Madinah with a cost of $24 \$$ billion and completion date at mid of 2019, Kingdom Tower, located in Jeddah which costed $1.8 \$$ billion and planned to be completed at March 2020, Abraj Kudai in Makkah with 3.5\$ billion with a planned completion date at the end of 2017 and Riyadh Metro project with a cost of $24.4 \$$ billion with a planned completion date at December 2020 [3], those only an example of the ongoing mega projects in KSA and not limited to the fact of the troubled projects in KSA, all that projects are still ongoing up to date with a schedule delay and cost overrun, all this give a trigger to study the risks which impact the Saudi market in case of mega projects in this research and also identifying those risks and analyzing it qualitatively to rank those identified risks according to the severity of every one to determine the most significant 15 risks which have the most negative impact on the project objectives, this was depending on a field survey to collect the data from different background expert engineers.

\section{Research Objectives}

The main objective of this research is to apply the best ways of managing the risk in case of mega construction projects starting from identifying it then following the proper procedures to analyze it to understand the impact of that identified risks in the project objectives specially the cost and time, in the line of this concept the detailed objectives was as following:

1. Investigating the risks affecting the execution of the construction mega projects in general and in KSA in particular to identify them.

2. Identifying the most significant risks which may impact objectives of the construction mega project in KSA.

3. Qualitatively analyze the identified risks to determine the severity of the identified risks and determine the Risk important index RII for each risk.

4. Depending on the analysis of the identified risks ranking them and determine the most significant 15 risks which impacting the objectives of the construction mega project in KSA for further quantitative analysis.

\section{RESEARCH METHODOLOGY}

The research depended on the data gathered from the literature review, interviews and different data gathering techniques and the Questionnaire survey which answered by qualified expert engineers in the field of construction Megaproject especially in Saudi 
Arabia and other areas with a closed feedback related to the construction market at Saudi Arabia.

Statistical analysis has been done to check the data collected from the questionnaire and ensure its validity and reliability then an application of the qualitative analysis which resulted in descending ranking for the Identified risks by the calculating of the Risk Important Index (RII) and determine the risk importance to identify the list of most significant 15 risks.

\section{Literature Mega projects definition and characteristics.}

The term megaproject was coined in the 1970s to characterize the size and cost of large-scale energy development projects being undertaken around the world [4] and used to describe very large capital projects costing millions of U.S. dollars [5].

Adnan Haidar [6]. Stated that there no specific definition of mega projects moreover here is no definite understanding of what differentiates it from any other large or complex project. Also, they explain that the most common agreement among practitioners and researchers is the concept of a large-scale project with a price tag is excess of one billion dollar and usually lead to cost overrun.

There are numerous definitions of megaprojects throughout the construction literature. However, most definitions provided place megaprojects not in their construction management context but in a wider public planning and economy context. For instance, megaprojects are defined as significant undertakings characterized by multi-organizations seeking success on different objectives subject to sociopolitical impacts [7]. Other definitions consider megaprojects as projects that have a strikingly poor performance in terms of economy, environment, and public support. Also, they lead to cost overruns and lower-than-predicted revenues that hinder economic growth instead of advancing it [8]

The Federal Highway Administration (FAHWA) defines megaprojects as: Major infrastructure projects that cost more than $\$ 1$ billion, or projects of a significant cost that attract a high level of public attention or political interests because of substantial direct and indirect impacts on the community, environment, and state budgets [6] highlighted that more elaborate definitions of megaprojects describe it as large-scale complex projects that often fail to meet costs estimations, time schedules, and anticipated project outcomes [9]. Define megaprojects as projects that contain a large element of technological innovation associated with high risk and characterized by conflict, uncertainty, and poor cooperation between partners.
Mega project a concept of growing importance in today's globally connected business environment, requires a closer examination because of the expansion of global networks, increasing collaborations among numerous partners, and the complexity of managing such projects [10]. Also, that king of projects can be defined as a large-scale manufacturing or infrastructure undertakings which transform landscapes rapidly and profoundly in very visible ways. They involve coordinated applications of capital, sophisticated technology, intense planning, and political influence. They require the engagement of numerous contractors, often from various countries, and take years for completion [11].

Prince Boateng A [12] define the mega projects as complex and expensive projects that often involve social, technical, economic, environmental and political (STEEP) challenges to project management. And they considered the (STEEP) category of risk and accordingly they adopted the Analytical Network Process and combined it with a new Risk Priority Index as an innovative approach to model risks analytically based on data collected from the Edinburgh Tram Network project at the construction phase.

Merrow [13], stated that Megaprojects have a number of characteristic traits that are closely associated with many of the headaches that are presumed to accompany very large projects as following:

Megaprojects tend to stretch available resources to the limit (and sometimes beyond) resources such as labor, supplies of bulk materials such as concrete and pipe, managerial skills, and information systems.

Megaprojects are often built-in areas with inadequate basic infrastructure, i.e., transportation, communications, housing, and health and sanitation facilities.

The climate may be hostile and the culture alien to those responsible for project management. Megaprojects often have a high profile within the sponsoring firms and agencies and in the politics of the host countries or political subdivisions.

Mega Projects rarely go unnoticed by regulators. The success of these projects is so important to their sponsors that firms and even governments can collapse when they fail.

Finally, megaprojects are usually long projects; thus, there is ample time for things that affect project outcomes to change, and there is less likelihood of maintaining continuity in project management. 
Abdulmoneim AM et al., Saudi J Civ Eng, Mar, 2021; 5(2): 35-49

T. Zidanea [2] in their research about (Megaprojects - Challenges and Lessons Learned) sum up a Table-1 of megaprojects characteristics depending on a litterateur overview of the megaprojects research:

Table-1: Megaproject Characteristics and Descriptions [2]

\begin{tabular}{|l|l|}
\hline Element & Characteristic and Description \\
\hline Size & Large Scale Project (huge Scope) Technologically and logistically demanding \\
\hline Cost & Exceed One Billion US dollar \\
\hline Time & $\begin{array}{l}\text { Exceed 5 years Long" duration } \\
\text { Program urgency }\end{array}$ \\
\hline Success & $\begin{array}{l}\text { Different objectives. } \\
\text { Fail to meet costs estimations, time schedules, and anticipated project outcomes Goal- } \\
\text { orientation (technical, financial, time) } \\
\text { Poor performance in term of economy, environment, and public support. } \\
\text { Leads to cost overuns and lower than-predicted revenues that hinder economic growth } \\
\text { instead of advancing it. }\end{array}$ \\
\hline Complexity & $\begin{array}{l}\text { Requires the management of numerous, concurrent, and complex activities. } \\
\text { Contains a large element of technological innovation }\end{array}$ \\
\hline Impact & $\begin{array}{l}\text { Impacts on the community, environment, state budgets. } \\
\text { Socio-political impacts }\end{array}$ \\
\hline Singularity & Unique, no mega projects look like another \\
\hline $\begin{array}{l}\text { Stakeholders and } \\
\text { Shareholders }\end{array}$ & $\begin{array}{l}\text { Attracts a high level of public attention or political interests. } \\
\text { The nature and number of project owners } \\
\text { Conflicts, poor cooperation between partners. }\end{array}$ \\
\hline Uncertainty & Associated with high rank risk. \\
\hline $\begin{array}{l}\text { Implementation } \\
\text { Owner }\end{array}$ & $\begin{array}{l}\text { Requiring multidisciplinary inputs from many organizations } \\
\text { A "virtual enterprise" for the execution of the project. }\end{array}$ \\
\hline Knowledge & New subject of research \\
\hline
\end{tabular}

Megaprojects are characterized also by complexity, uncertainty, ambiguity, dynamic interfaces, significant political or external influences, and time periods reaching a decade or more [14].They also involves international participants with a variety of cultural differences, backgrounds, political systems, and languages [15].

\section{Literature of Risk Factors in KSA Project}

The literature done to study major factors impacting the construction projects in KSA, according to [16] the research studied the main causes of delay in large building projects in Saudi Arabia and their relative importance. A survey of a randomly selected sample of 24 contractors, 15 architectural engineering firms (A/E), and nine owners from the Eastern Province of Saudi Arabia was undertaken. The survey included 56 causes of delay, and the respondents were asked to indicate their degree of importance. The delay factors were grouped into nine major groups. The level of importance of the causes and the groups were measured and ranked by their importance index for contractors, owners and $(\mathrm{A} / \mathrm{E})$. It was shown that the financing group of delay factors was ranked the highest by all three parties and that environment was ranked the lowest.

Another study conducted by Mohammed I. AlKhalil and Mohammed A. Al-Ghafly [17]. This study was conducted to determine the most important causes of delay in public utility projects, based on the frequency and severity of the causes. A survey of randomly selected samples of contractors, consultants, and owners was carried out to assess the frequency of occurrence and the severity of impact of sixty potential delay causes. The analysis showed lack of agreement among the parties on the ranking of the major categories of delay. contractor performance risk group was ranked highest in importance by the consultant and second highest by the owner, but the contractor considered it to be the least important of all categories of delay. Early planning and design risk group was ranked as a group as the most important delay category by the owner. The contractor and consultant ranked it a tie with government regulation risk group. While site and environmental conditions delay category came as the least important by the owner and ranked 5 and 4 by the contractor and consultant, respectively. Finally, Site supervision as a group the contractor considered the consultant site supervision as a major delay category. It was ranked second in importance by the contractor but as low as 5 and 6 by the owner and consultant, respectively. Among the most important causes found are cash flow problems and financial difficulties by the contractor, difficulties in obtaining permits, and the requirement to select the lowest bidder without regard to prequalification.

This was followed by a well-established study by [1] outlining 73 risks in large construction projects. These risks were classified into eight categories based on the sources from which the risks could be generated: 
Abdulmoneim AM et al., Saudi J Civ Eng, Mar, 2021; 5(2): 35-49

the project, owner, contractor, consultant, design, materials, labor and equipment. The field survey conducted included 23 contractors, 19 consultants, and 15 owners. The most common cause of delay identified by all the three parties is "change order". Surveys concluded that $70 \%$ of projects experienced time overrun and found that 45 out of 73 projects considered were delayed.

As per [18]. The survey covers a sample of 86 clients, contractors and consultants working in the Saudi construction industry. These are contained in seven groupings: client, contractor, consultant, materials, labor, contract and relationship-related causes. The main results, therefore, are disaggregated to reflect the views of each respondent group concerning each group of causes. In general, however, it is found that the most influencing current cause of delay is the lack of qualified and experienced personnel attributed to the considerable amount of large, innovative, construction projects and associated current undersupply of manpower in the industry.
On another hand [19] studied Saudi Arabian aviation construction projects. it has been found that these projects are still delivered with a significant number of time and cost overruns. These consequences are typically generated from the risks involved in the projects. So, the aim of this study was twofold: to identify risks associated with aviation construction projects in Saudi Arabia and, second, to evaluate the consequences of these risks on a number of GACA projects. As a result, 54 new risks have been identified and classified into three levels: internal, external and force majeure. Results have confirmed the existence of time and cost overruns for GACA projects.

A well-established study by Nasser Alotaibi et al. [20] examines the critical factors contributing to the construction delays in KSA and identifies potential contributions of project management tools and techniques to minimizing them. The author summarizes the Table-2indicates the agreement between authors on different factors that contribute to delay experienced in construction projects in KSA as shown below.

Table-2: Critical Factors Contributing to Delays in KSA [20]

\begin{tabular}{|c|c|}
\hline Delay Causes & Authors \\
\hline $\begin{array}{l}\text { Ineffective planning and scheduling of the } \\
\text { project by the contractors }\end{array}$ & $\begin{array}{l}\text { Assaf et al.,1995; Alkalil \& Al-Ghafly, 1999; (Falqi, 2004); } \\
\text { Assaf \& Al-Hejji, 2006; Al-Kharashi \& Skitmore, } 2009\end{array}$ \\
\hline $\begin{array}{l}\text { Poor qualification, skills and experience of the } \\
\text { contractors'staff }\end{array}$ & $\begin{array}{l}\text { Assaf et al.,1995; Alkalil \& Al-Ghafly, 1999; (Falqi, 2004); } \\
\text { Assaf \& Al-Hejji, 2006; Al-Kharashi \& Skitmore, } 2009\end{array}$ \\
\hline Delay in progress payment by the client & $\begin{array}{l}\text { Al-Mudlj 1984; Al-Hzmi, 1987; Al-Subaie, 1987; Alkalil \& Al- } \\
\text { Ghafly 1999; (Falqi, 2004); Assaf \& Al-Hejji, 2006; Al- } \\
\text { Kharashi \& Skitmore, 2009 }\end{array}$ \\
\hline Changes during construction & $\begin{array}{l}\text { Alkalil \& Al-Ghafly 1999; Assaf \& Al-Hejji, 2006; Al-Kharashi } \\
\text { \& Skitmore, } 2009\end{array}$ \\
\hline
\end{tabular}

According to the study conducted [21] the paper identifies the main causes of delay in infrastructure projects in Mecca, Saudi Arabia, and compares these with projects around the country and other Gulf countries. Data was obtained from 49 infrastructure projects undertaken by the owner and were analyzed quantitatively to understand the severity and causes of delay. 10 risk factors were identified and were grouped into four categories. Average delay in infrastructure projects in Mecca was found to be $39 \%$.
The most severe cause of delay was found to be the land acquisition factor.

The 10 identified risks in that study were ranked and concluded in four main groups. It is concluded that the majority of project delays were caused from the owner's side as compared to contractors, consultants, and other project's stakeholders.

Table-3: Identified Risks with related group [21]

\begin{tabular}{|c|c|c|}
\hline No & Risk & Related Group \\
\hline 1 & Land acquisition & \multirow{4}{*}{ Owner } \\
\hline 2 & Line services (Utilities and underground services) & \\
\hline 3 & Re-designing & \\
\hline 4 & Variation in estimated quantities & \\
\hline 5 & Contractors' lack of expertise & \multirow{2}{*}{ Contractor } \\
\hline 6 & Deliberate delay in construction by the GC & \\
\hline 7 & Change of consultant during project execution & Consultant \\
\hline 8 & Differences in opinions from the Ministry of Traffic & \multirow{3}{*}{$\begin{array}{l}\text { Other Stakeholders (local public, land } \\
\text { Owners, etc.) }\end{array}$} \\
\hline 9 & Clashes with other Ministries & \\
\hline 10 & Miscommunication between various stakeholders & \\
\hline
\end{tabular}


Finally, the study conducted by Mohammed Algahtany et al. [22]. This study is conducted to investigate the risks that are out of contractors' control (caused by other parties) in the context of the Saudi construction industry and reports ranked list of risks that are out of contractors' control according to contractors' viewpoint through a questionnaire survey. Thirty-six risk factors that are out of contractors' control were identified through literature review and a pilot study. The study concluded that the top risks that are out of contractors' control in public construction projects in Saudi Arabia are: delay in progress payments by owner, owners' practice of assigning contracts to lowest bidder, slow decision making by the owner, change orders by owner during construction, excessive bureaucracy in the owner's administration, delay in approving major changes in the scope of work by consultant, and external work due to public agencies (roads, utilities and public services). The study recommends contractors to identify the risks that are out of their control before projects starts and identify how to mitigate these risks with the project parties during execution phase.

\section{List of Identified Risks and Identification Methodology}

Risk identification determines what might happen that could affect the objectives of the project and how those things might happen. Risk identification is an iterative process because new risks may become known as the project progresses through its life cycle, previously identified risks may drop out, and other risks may be updated [23].

Hillson [24] and PMI [25] mentioned that there are many techniques exist for risk identification, such as brainstorming and workshops, checklists and prompt lists, questionnaires and interviews, etc). They were sure that there is no single "best method" for risk identification.
There are many risks that might impact a project success. So, it is important to identify the project risks early in the project life cycle. Risk identification can be defined as the process of identifying individual project risks as well as sources of overall project risk and documenting their characteristics [25]. This process is performed throughout the project life cycle, but it should be in the early stages of the project.

The main aim of this step is to identify the possible risks that might impact the megaprojects in KSA this is to optimize management and construction of that kind of project by giving a list of significant risks which may impact that projects, by the direct contact with the mega project experts in KSA, in this paper this list of risks will be considered during the risk analysis process. An extensive essential step conducted to determine the list of risks which can be summarized as following:

Literature review: where several papers, thesis, and references are reviewed to prepare a primary list of risk factors.

Interviews: with several project managers, consultant engineers, and site engineers with total number of experts reached to 30 experts those who execute Megaprojects.

Primary list has been modified according to expert's opinion; they added, modified and deleted risk factors which considered as a low priority from the primary list to reach the final list.

As a result of this methodology 57 risks has been identified. The hierocracy of that identified list of risk depended on Two main groups which were internal risks and external risks and 8 sub-groups as shown in the below Table-4:

Table-4: List of the identified risks subgroup

\begin{tabular}{|l|l|l|}
\hline Risk Main Group & Risk Subgroup Code & Risk Subgroup Discerption \\
\hline \multirow{4}{*}{ External Risk } & A & Social Risks \\
\cline { 2 - 3 } & B & Economic \& Financial Risk \\
\cline { 2 - 3 } & C & Political \& Governmental Risk \\
\hline \multirow{5}{*}{ Internal Risk } & D & Technical Risks \\
\cline { 2 - 3 } & E & Procurement Risk \\
\cline { 2 - 3 } & F & Contractual Risks \\
\cline { 2 - 3 } & G & Construction Risk \\
\cline { 2 - 3 } & H & Risks Related to Mega Projects Characteristics \\
\hline
\end{tabular}

Also, the final list of the idented risk can be

demonstrated in the below

Table-5 and can be summarized in the hierarchy structure at Fig-1 which showing the RBS. 
Table-5: Final List of the identified risks

\begin{tabular}{|c|c|c|c|}
\hline $\begin{array}{l}\text { Risk Main } \\
\text { Group }\end{array}$ & Risk Subgroup & $\begin{array}{l}\text { Risk } \\
\text { Code }\end{array}$ & Risk Discerption \\
\hline \multirow{15}{*}{$\begin{array}{l}\text { External } \\
\text { Risk }\end{array}$} & \multirow{5}{*}{$\begin{array}{l}\text { Social Risks } \\
\text { (A) }\end{array}$} & A1 & Very high cost of compensations due to megaproject requirements. \\
\hline & & $\mathrm{A} 2$ & Over cost due to labor disputes because of the different culture \\
\hline & & A3 & The threat of project vandalism as a result of the lack of community acceptance \\
\hline & & A-4 & $\begin{array}{l}\text { Change of legal action related to the labor system and work which may lead to Impose } \\
\text { additional taxes on foreign labor }\end{array}$ \\
\hline & & A-5 & Administrative Corruption \\
\hline & \multirow{4}{*}{$\begin{array}{c}\text { Economic \& } \\
\text { Financial Risk } \\
\text { (B) }\end{array}$} & B1 & $\begin{array}{l}\text { Unanticipated inflation due to an instability of the economic situation and Currency } \\
\text { fluctuation during construction stage. }\end{array}$ \\
\hline & & $\mathrm{B} 2$ & $\begin{array}{l}\text { Incas of governmental Mega project, as a result of the economic recession the government } \\
\text { payment policy change or financing has stalled }\end{array}$ \\
\hline & & B3 & $\begin{array}{l}\text { Shortage of contractor cash out during the negative period of cash flow when expenditures } \\
\text { are higher than incoming payments. }\end{array}$ \\
\hline & & B4 & Interest Rates and the schedule slippage \\
\hline & \multirow{6}{*}{$\begin{array}{c}\text { Political \& } \\
\text { Governmental } \\
\text { Risk (C) }\end{array}$} & $\mathrm{C} 1$ & termination of the project due to the economic policy change \\
\hline & & $\mathrm{C} 2$ & The difficulty of taking the required governmental approvals due to the project complexity \\
\hline & & $\mathrm{C} 3$ & The entry of the state into a forced war leading to depletion of its resources \\
\hline & & $\mathrm{C} 4$ & Demonstration and political instability \\
\hline & & C5 & Frequent changes in government \\
\hline & & C6 & The impact of complex import and export regulation \\
\hline \multirow{30}{*}{$\begin{array}{l}\text { Internal } \\
\text { Risk }\end{array}$} & \multirow{9}{*}{$\begin{array}{l}\text { Technical } \\
\text { Risks (D) }\end{array}$} & D1 & $\begin{array}{l}\text { Inadequate project complexity analysis which leads to technical problems starting from } \\
\text { design phase }\end{array}$ \\
\hline & & D2 & Delay of Design Drawing and then Shop Drawing \\
\hline & & D3 & $\begin{array}{l}\text { Discrepancy between shop drawing and design drawing for the same discipline and Miss } \\
\text { coordination between structural, architectural and MEP drawing. }\end{array}$ \\
\hline & & D4 & $\begin{array}{l}\text { Delay of providing the client to the requirements of some special items like low current } \\
\text { system. }\end{array}$ \\
\hline & & D5 & 5 Poor estimation of the project cost due to the project complexity and huge size. \\
\hline & & D6 & The difficulty of material approval due to a high level of project specifications \\
\hline & & D7 & Lack of geotechnical and hydrology study. \\
\hline & & D8 & $\begin{array}{l}\text { Conflict and miss coordination between the different consultant in the project during design } \\
\text { stage }\end{array}$ \\
\hline & & D9 & $\begin{array}{l}\text { Low technical office productivity of the required shop drawing for construction which is } \\
\text { disproportionate with the site productivity. }\end{array}$ \\
\hline & \multirow{8}{*}{$\begin{array}{l}\text { Procurement } \\
\text { Risks (E) }\end{array}$} & E1 & Very high cost of compensations due to megaproject requirements. \\
\hline & & E2 & The limitation of suppliers or manufacture if compared to the project huge size. \\
\hline & & E3 & $\begin{array}{l}\text { Providing inadequate information and/or failure to adequately address enquirers to the } \\
\text { Vendors lead to a variation in offer and or a conflict during the execution }\end{array}$ \\
\hline & & E4 & Selecting an inappropriate supplier or subcontractor lead to failure to fulfill the contract. \\
\hline & & E5 & Complexity of the procedures of requesting and purchasing process \\
\hline & & E6 & $\begin{array}{l}\text { Shortage of materials in the market due to the huge requirement and material specialty } \\
\text { Related to mega project characteristics }\end{array}$ \\
\hline & & E7 & Improper Long Lead Items Managements From the procurement department point of view. \\
\hline & & E8 & Lack of construction martial due to delay of supplier payment \\
\hline & \multirow{4}{*}{$\begin{array}{l}\text { Contractual } \\
\text { Risks (F) }\end{array}$} & F1 & $\begin{array}{l}\text { Inappropriate contract administration due to Misunderstanding type and strategy for the } \\
\text { contract. }\end{array}$ \\
\hline & & F2 & Misunderstanding of some contract terms \\
\hline & & F3 & Stiff funding strategy contractual terms \\
\hline & & F4 & Lack of clear party relations in the contract clauses \\
\hline & \multirow{9}{*}{$\begin{array}{l}\text { Construction } \\
\text { Risk (G) }\end{array}$} & G1 & $\begin{array}{l}\text { Miss understanding of the project nature which leads to inadequate work sequence and } \\
\text { improper construction methodology }\end{array}$ \\
\hline & & G2 & Miss coordination between project parties. during construction. \\
\hline & & G3 & Rework due to lack of quality control system \\
\hline & & G4 & Change of key staffing throughout the project. \\
\hline & & G5 & Low labor productivity due to poor supervision \\
\hline & & G6 & Poor site storage management \\
\hline & & G7 & Poor experienced supervision consultant \\
\hline & & G8 & A lot of design changes during construction \\
\hline & & G9 & Low construction productivity due to lack of and /or deteriorated equipment \\
\hline
\end{tabular}


Abdulmoneim AM et al., Saudi J Civ Eng, Mar, 2021; 5(2): 35-49

\begin{tabular}{|c|c|c|c|}
\hline $\begin{array}{l}\text { Risk Main } \\
\text { Group }\end{array}$ & Risk Subgroup & $\begin{array}{l}\text { Risk } \\
\text { Code }\end{array}$ & Risk Discerption \\
\hline & & G10 & Safety and health risks: such as the death of some workers or labor injures \\
\hline & & G11 & The Impact of Nature of Climate and Terrain up on the project during construction. \\
\hline & \multirow{10}{*}{$\begin{array}{c}\text { Risks Related } \\
\text { to Mega } \\
\text { Projects } \\
\text { Characteristics } \\
\text { (H) }\end{array}$} & $\mathrm{H} 1$ & $\begin{array}{l}\text { Megaprojects are often built in areas with inadequate basic Condition (infrastructure, } \\
\text { transportation, communications, housing, and health and sanitation facilities) }\end{array}$ \\
\hline & & $\mathrm{H} 2$ & $\begin{array}{l}\text { Due to the megaproject majority, the success is very important for their sponsors that firms } \\
\text { and its falling may lead to governments collapse and this is impacting the project stability }\end{array}$ \\
\hline & & $\mathrm{H} 3$ & $\begin{array}{l}\text { Due to the large size of the megaprojects the workforce is consists of a number of work } \\
\text { group that manage in parallel Which leading to lack of management and an inactivity of } \\
\text { work crews at the operation level }\end{array}$ \\
\hline & & $\mathrm{H} 4$ & $\begin{array}{l}\text { The increase in complexity would impose Technical and functional support which would } \\
\text { add to the managerial efforts required to handle a complicated design }\end{array}$ \\
\hline & & H5 & $\begin{array}{l}\text { High level of stockholder attention leads to Conflicts and poor cooperation between } \\
\text { partners. }\end{array}$ \\
\hline & & H6 & $\begin{array}{l}\text { Huge budget and very long duration give a chance of cost over run and schedule slippage } \\
\text { due to lack of cost and time management. }\end{array}$ \\
\hline & & $\mathrm{H} 7$ & $\begin{array}{l}\text { Due to the megaproject complexity, a special execution sequence and technological } \\
\text { innovation are required, all this may impact the time and project cost. }\end{array}$ \\
\hline & & $\mathrm{H} 8$ & Gold plating due to unclear scope. \\
\hline & & H9 & Unrealistic schedules and budgeting Due to inadequate project plan. \\
\hline & & $\mathrm{H} 10$ & Technological innovation requirements due to project complexity. \\
\hline
\end{tabular}

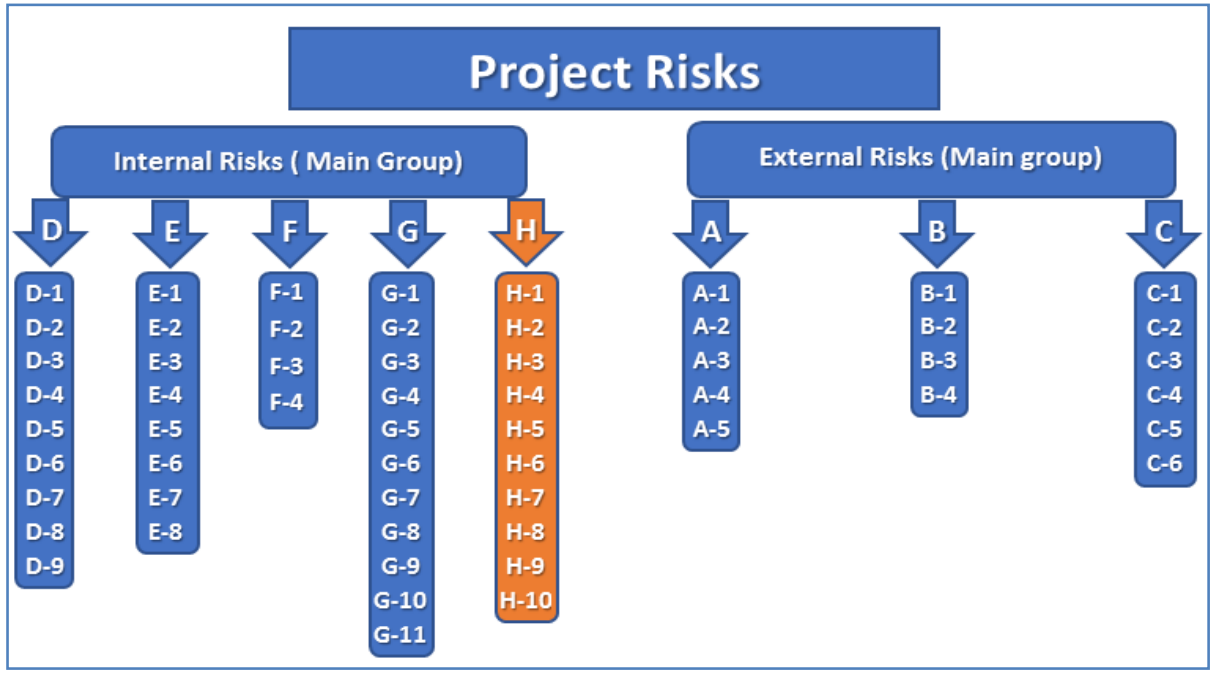

Fig-1: Risk Breakdown structure for the Identified Risk (RBS)

Depending on the collected data and according to the explained methodology which leaded to identify the risks impacting mega projects in KSA the structure of the questionnaire has been built and then sent to the participants to determine the probability of each risk and its impact in the project objectives. In this paper the qualitative analysis depended on the result of the questionnaire and the participant's respected reply's, the risk important index has been calculated and then the ranking for the identified risks has been done.

\section{Feld survey}

The Survey method is the technique of gathering data by asking questions to people who are thought to have desired information. In this research the field survey was one of the main source of date and research results.
The Questionnaire used in this research to evaluate the identified risk factors and to determine two parameters for each risk factor. Those parameters are the probability of occurrence and the impact of each risk in the project objectives.

To collect the required date for this research a literature review through the books, web site, statistics, researches in the same field, and magazines has been done, plus primary resources not available in traditional resources, through distribution questionnaire on the study population in order to obtain their views on the questionnaire. The main aim of this questionnaire was to identify two attributes for each risk. These attributes are probability of occurrence and degree of impact in the risk affecting the construction companies working in the field of Mega projects in the kingdom of Saudi Arabia (KSA) in order to analyze the effect of the identified risks on this kind of projects objectives (Cost, 
Time, \& Quality) and then determine the importance index to ranking those risks depending on its degree of importance which reflect the severity of every risk as well.

\section{Statistical Sample Determination}

COCHRAN [26], developed a formula to calculate a representative sample and the sample soze calculated depending on it as following equation:

$\mathrm{SS}=\frac{\mathbf{z}^{\mathbf{2}} \times \mathbf{p}(\mathbf{1}-\mathbf{p})}{\mathbf{e}^{\mathbf{2}}} \quad$ Equation 01

Where $\mathrm{Z}=1.64$ at $95 \%$ confidence level, $\mathrm{P}=0.2$, $\mathrm{e}=8 \%$ SS $($ Sample Size $)=\frac{1.64^{2} \times 0.2(1-0.2)}{0.08^{2}}=68$

The participants were 80 engineers from different backgrounds, 2 answers ignored the remaining participants were 78 .

\section{Respondents profile}

The respondent's profile is represented in Table- 6 where near of $67 \%$ of the respondents were a civil engineer while there were near of $60 \%$ of them were working in a contactor companies $30 \%$ were consultants. In terms of respondent's educational level most of the respondents are between BScs. and MSc $49 \%$ and $44 \%$ respectively. Beside that $26 \%$ of the respondents having more than 20 of experience, $40 \% 15$ to 20 years of experience and $19 \% 10$ to 15 years of experience which mean that $85 \%$ of the respondents have more than 10 years of experience most of them in a managerial level as we have as shown in Table-6. On another hand $90 \%$ of the respondents have an experience in mega project at Saudi Arabia and this is reflecting positively on the questionnaire results. The last concerned issue that $55 \%$ of the respondents mega projects were having a schedule slippage and / or cost overrun due to risk occurrence and this means that the respondents were interested in the risk study to find a solution to their projects.

Table-6: The profile of the respondents

\begin{tabular}{|c|c|c|c|}
\hline Category & Characteristics & Frequency & Percentage $(\%)$ \\
\hline \multirow[t]{5}{*}{ Company business Field } & Owner & 4 & $5 \%$ \\
\hline & Consultant & 23 & $30 \%$ \\
\hline & Contractor & 46 & $59 \%$ \\
\hline & $\mathrm{PMO} / \mathrm{PMC}$ & 4 & $5 \%$ \\
\hline & Other & 1 & $1 \%$ \\
\hline \multirow[t]{5}{*}{ Profession } & Civil Eng. & 52 & $80 \%$ \\
\hline & Architect Eng. & 16 & $20 \%$ \\
\hline & Mechanical Eng. & 3 & $4 \%$ \\
\hline & Electrical Eng. & 3 & $4 \%$ \\
\hline & Other Engineering & 4 & $5 \%$ \\
\hline \multirow[t]{4}{*}{ Highest Academic Degree } & Bachelor & 43 & $49 \%$ \\
\hline & Master & 38 & $44 \%$ \\
\hline & Post graduate diploma & 5 & $6 \%$ \\
\hline & Doctorate & 1 & $1 \%$ \\
\hline \multirow[t]{5}{*}{ Years of Experience } & one to Five & 1 & $1 \%$ \\
\hline & Five to Ten & 12 & $1 \%$ \\
\hline & Ten to Fifteen & 14 & $19 \%$ \\
\hline & Fifteen to Twenty & 31 & $40 \%$ \\
\hline & $>$ Twenty & 20 & $26 \%$ \\
\hline \multirow[t]{8}{*}{ Position in construction firm } & Chairman & 1 & $1 \%$ \\
\hline & $\mathrm{CEO}$ & 2 & $3 \%$ \\
\hline & Executive Director & 2 & $3 \%$ \\
\hline & Project Manager & 2 & $3 \%$ \\
\hline & Risk Manager & 18 & $23 \%$ \\
\hline & QA/QC Manager & 17 & $22 \%$ \\
\hline & Construction Manager & 16 & $20 \%$ \\
\hline & Other (Junior, Senor Eng.) & 20 & $25 \%$ \\
\hline \multirow[t]{2}{*}{ Having Megaproject Experience in KSA } & yes & 70 & $90 \%$ \\
\hline & No & 8 & $10 \%$ \\
\hline \multirow{4}{*}{$\begin{array}{l}\text { schedule slippage and / or cost overrun due to risk } \\
\text { occurrence }\end{array}$} & Always & 20 & $26 \%$ \\
\hline & Often & 23 & $29 \%$ \\
\hline & Sometimes & 32 & $41 \%$ \\
\hline & Never & 3 & $4 \%$ \\
\hline
\end{tabular}




\section{Qualitative Analysis for the Data}

One of the most important steps in the risk management process is qualitative analysis which aims to rank and prioritization the identified risk in the project depending on its severity. In the questionnaire the respondent assessed the risks by giving the score to the probability and impact of those risks using the given values in the

Table-7 to determine the risk importance index for each identified risk according to the 5-point scale. A risk's probability scale naturally falls between 0.0 (no probability) and 1.0 (certainty).

An ordinal scale, representing relative probability and impact values from very Low to very high could be used. Alternatively, specific probability and impact could assign by using a general scale as shown in

Table-7

Table-7: Ordinal Scale represents relative Probability and Impact factors with equivalent values

\begin{tabular}{|l|l|l|l|l|l|}
\hline Criteria & Very Low & Low & Moderate & High & Very High \\
\hline Scale & 0.1 & 0.3 & 0.5 & 0.7 & 0.9 \\
\hline
\end{tabular}

Importance index is used to assess the relative significance among risk factors, and then ranking these risks. It depends on probability index and impact index. The probability index (P.I) and impact index (I.I) of each factor will be calculated by the following formulas [27].

P.I. $=[\stackrel{5}{5}(\mathrm{PS} * \mathrm{XPS}) /(\mathrm{n} * 0.9)] * 100$

$$
\mathrm{S}=1
$$

I.I. $\quad=[\stackrel{5}{5}(\mathrm{IS} * \mathrm{X}$ IS $) /(\mathrm{n} * 0.9)] * 100$

Equation 03

$\mathrm{S}=1$

Where:-

(PS) is Constant expressing the weight assigned to option (S) on the probability of occurrence scales, as shown in

Table-7
(IS) is Constant expressing the weight assigned to option (S) on the degree of impact scales, as shown in

Table-7

(X PS) is Variable expressing number of responded who selected option (s) for probability of occurrence.

(X IS) is Variable expressing number of responded who selected option (s) for degree of impact.

(n) Is Total number of respondents.

Then the importance index (IMP.IND.) will be calculated by the following formula:

RII $\%=($ P.I. $*$ I.I. $) * 100$

Equation 04

An example of calculating the P.I and I.I and the RII depending on the formulas $1,2 \& 3$, the values at

Table-7 and the respondent reply to the questionnaire for risk factor \# A-1 can be explained as below:

\begin{tabular}{|l|l|l|l|l|l|}
\hline \multirow{2}{*}{ Risk Code } & \multicolumn{4}{|l|}{ Probability } & \multicolumn{1}{l|}{} \\
\cline { 2 - 6 } & V. High (0.9) & High (0.7) & Moderate (0.5) & Low (0.3) & V. Low (0.1) \\
\hline A-1 & 2 & 29 & 30 & 14 & 3 \\
\hline
\end{tabular}

\begin{tabular}{|l|l|l|l|l|l|}
\hline \multirow{2}{*}{ Risk Code } & \multicolumn{5}{|l|}{ Impact } \\
\cline { 2 - 6 } & V. High (0.9) & High (0.7) & Moderate (0.5) & Low (0.3) & V. Low (0.1) \\
\hline A-1 & 10 & 38 & 24 & 6 & 0 \\
\hline
\end{tabular}

\footnotetext{
P.I. $=\left[\sum(\mathrm{PS} * \mathrm{X}\right.$ PS $\left.) /(\mathrm{n} * 0.9)\right] * 100$

Equation 02

RII. $\%=($ P.I. $*$ I.I. $) * 100$

Equation 04

I.I. $=\left[\sum(\mathrm{IS} * \mathrm{X}\right.$ IS $\left.) /(\mathrm{n} * 0.9)\right] * 100$

Equation 03 
Abdulmoneim AM et al., Saudi J Civ Eng, Mar, 2021; 5(2): 35-49

As per the explanation above and depending on the respondents to the published questionnaire repliers the P.I, I.I and the RII are calculated, and Depending on the RII, the identified risks are ranked
Table-8 is showing the ranking factor of each Identified risk.

Table-8: Risk Ranking depending on the RII

\begin{tabular}{|c|c|c|c|c|c|}
\hline Risk Group & Risk Code & Probability Index & Impact Index & Risk Importance Index RII & Ranking \\
\hline \multirow[t]{5}{*}{ Group A } & A-1 & 0.5926 & 0.7037 & 41.70 & 13 \\
\hline & A-2 & 0.4302 & 0.5043 & 21.69 & 56 \\
\hline & A-3 & 0.3504 & 0.6154 & 21.56 & 57 \\
\hline & A-4 & 0.6410 & 0.7350 & 47.12 & 5 \\
\hline & $\mathrm{A}-5$ & 0.5726 & 0.7521 & 43.07 & 11 \\
\hline \multirow[t]{4}{*}{ Group B } & B1 & 0.5385 & 0.7721 & 41.57 & 14 \\
\hline & $\mathrm{B} 2$ & 0.6353 & 0.7564 & 48.06 & 2 \\
\hline & B3 & 0.6353 & 0.7493 & 47.60 & 3 \\
\hline & $\mathrm{B} 4$ & 0.5527 & 0.6453 & 35.67 & 31 \\
\hline \multirow[t]{6}{*}{ Group C } & $\mathrm{C} 1$ & 0.4530 & 0.7578 & 34.33 & 40 \\
\hline & $\mathrm{C} 2$ & 0.5299 & 0.6781 & 35.93 & 28 \\
\hline & $\mathrm{C} 3$ & 0.4017 & 0.8376 & 33.65 & 43 \\
\hline & $\mathrm{C} 4$ & 0.4217 & 0.7179 & 30.27 & 53 \\
\hline & $\mathrm{C} 5$ & 0.4274 & 0.5869 & 25.08 & 55 \\
\hline & C6 & 0.4986 & 0.6353 & 31.68 & 48 \\
\hline \multirow[t]{9}{*}{ Group D } & D1 & 0.5798 & 0.7778 & 45.09 & 8 \\
\hline & D2 & 0.5783 & 0.7265 & 42.02 & 12 \\
\hline & D3 & 0.5897 & 0.7607 & 44.86 & 9 \\
\hline & D4 & 0.5157 & 0.6524 & 33.64 & 44 \\
\hline & D5 & 0.5584 & 0.8462 & 47.25 & 4 \\
\hline & D6 & 0.5271 & 0.6838 & 36.04 & 27 \\
\hline & D7 & 0.4986 & 0.7236 & 36.08 & 26 \\
\hline & D8 & 0.5185 & 0.6866 & 35.60 & 32 \\
\hline & D9 & 0.5385 & 0.6866 & 36.97 & 23 \\
\hline \multirow[t]{8}{*}{ Group E } & E1 & 0.5128 & 0.6923 & 35.50 & 33 \\
\hline & E2 & 0.5271 & 0.6895 & 36.34 & 24 \\
\hline & E3 & 0.5014 & 0.6895 & 34.57 & 39 \\
\hline & $\mathrm{E} 4$ & 0.5499 & 0.7236 & 39.79 & 16 \\
\hline & E5 & 0.4815 & 0.6353 & 30.59 & 51 \\
\hline & E6 & 0.5299 & 0.7151 & 37.89 & 21 \\
\hline & E7 & 0.5100 & 0.6838 & 34.87 & 36 \\
\hline & E8 & 0.5969 & 0.7236 & 43.19 & 10 \\
\hline \multirow[t]{4}{*}{ Group F } & $\mathrm{F} 1$ & 0.4929 & 0.7350 & 36.23 & 25 \\
\hline & $\mathrm{F} 2$ & 0.5071 & 0.7037 & 35.69 & 30 \\
\hline & F3 & 0.5014 & 0.6966 & 34.93 & 35 \\
\hline & $\mathrm{F} 4$ & 0.4615 & 0.6439 & 29.72 & 54 \\
\hline \multirow[t]{6}{*}{ Group G } & G1 & 0.4644 & 0.7265 & 33.74 & 42 \\
\hline & G10 & 0.4473 & 0.7436 & 33.26 & 45 \\
\hline & G11 & 0.4843 & 0.6610 & 32.01 & 47 \\
\hline & G2 & 0.5499 & 0.7009 & 38.54 & 20 \\
\hline & G3 & 0.5328 & 0.7379 & 39.31 & 17 \\
\hline & G4 & 0.5100 & 0.6809 & 34.72 & 38 \\
\hline
\end{tabular}


Abdulmoneim AM et al., Saudi J Civ Eng, Mar, 2021; 5(2): 35-49

\begin{tabular}{|c|c|c|c|c|c|}
\hline & G5 & 0.5527 & 0.7379 & 40.78 & 15 \\
\hline & G6 & 0.4900 & 0.6239 & 30.57 & 52 \\
\hline & G7 & 0.5157 & 0.6866 & 35.41 & 34 \\
\hline & G8 & 0.5897 & 0.7835 & 46.20 & 6 \\
\hline & G9 & 0.5214 & 0.6866 & 35.80 & 29 \\
\hline \multirow{10}{*}{ Group H } & $\mathrm{H} 1$ & 0.5726 & 0.6838 & 39.16 & 18 \\
\hline & $\mathrm{H} 10$ & 0.4929 & 0.6382 & 31.45 & 49 \\
\hline & $\mathrm{H} 2$ & 0.4644 & 0.7493 & 34.80 & 37 \\
\hline & $\mathrm{H} 3$ & 0.4986 & 0.6667 & 33.24 & 46 \\
\hline & $\mathrm{H} 4$ & 0.5755 & 0.6467 & 37.22 & 22 \\
\hline & $\mathrm{H} 5$ & 0.4758 & 0.6610 & 31.45 & 50 \\
\hline & H6 & 0.6182 & 0.7778 & 48.08 & 1 \\
\hline & $\mathrm{H} 7$ & 0.5613 & 0.6895 & 38.70 & 19 \\
\hline & $\mathrm{H} 8$ & 0.5014 & 0.6838 & 34.29 & 41 \\
\hline & H9 & 0.5812 & 0.7806 & 45.37 & 7 \\
\hline
\end{tabular}

\section{Importance of Risk Factors}

The importance index was calculated as the product of the probability of occurrence and the degree of impact index of the risk factor. The importance index is translated to a standard form with a base of 100 for relative comparison in the ranking tables.

The risk factors are evaluated according to their importance index, it is considered that the risk factors which have an importance index of more than or equal to $50 \%$ are considered very important, risk factors with $40 \%$ to $50 \%$ are important, risk factors with $30 \%$ to $40 \%$ are somewhat important, risk factors with $20 \%$ to $30 \%$ are slightly important, and those of less than 20 are not important [28]. Table-9 is showing the ranking of the risk factors according to the risk importance index.

Table-9: Ranking of the risk factors according to the risk importance index.

\begin{tabular}{|c|c|c|c|c|}
\hline Risk Group & Risk Code & $\begin{array}{l}\text { Risk Importance } \\
\text { Index RII \% }\end{array}$ & Ranking & $\begin{array}{l}\text { Risk Importance } \\
\text { Degree }\end{array}$ \\
\hline Group H & H6 & 48.08 & 1 & \multirow[t]{15}{*}{ Important } \\
\hline Group B & B2 & 48.06 & 2 & \\
\hline Group B & B3 & 47.6 & 3 & \\
\hline Group D & D5 & 47.25 & 4 & \\
\hline Group A & A4 & 47.12 & 5 & \\
\hline Group G & G8 & 46.2 & 6 & \\
\hline Group H & H9 & 45.37 & 7 & \\
\hline Group D & D1 & 45.09 & 8 & \\
\hline Group D & D3 & 44.86 & 9 & \\
\hline Group E & E8 & 43.19 & 10 & \\
\hline Group A & A5 & 43.07 & 11 & \\
\hline Group D & D2 & 42.02 & 12 & \\
\hline Group A & A1 & 41.7 & 13 & \\
\hline Group B & B1 & 41.57 & 14 & \\
\hline Group G & G5 & 40.78 & 15 & \\
\hline Group E & $\mathrm{E} 4$ & 39.79 & 16 & \multirow[t]{14}{*}{ Somewhat important } \\
\hline Group G & G3 & 39.31 & 17 & \\
\hline Group H & $\mathrm{H} 1$ & 39.16 & 18 & \\
\hline Group H & $\mathrm{H} 7$ & 38.7 & 19 & \\
\hline Group G & G2 & 38.54 & 20 & \\
\hline Group E & E6 & 37.89 & 21 & \\
\hline Group H & $\mathrm{H} 4$ & 37.22 & 22 & \\
\hline Group D & D9 & 36.97 & 23 & \\
\hline Group E & E2 & 36.34 & 24 & \\
\hline Group F & F1 & 36.23 & 25 & \\
\hline Group D & D7 & 36.08 & 26 & \\
\hline Group D & D6 & 36.04 & 27 & \\
\hline Group C & $\mathrm{C} 2$ & 35.93 & 28 & \\
\hline Group G & G9 & 35.8 & 29 & \\
\hline
\end{tabular}


Abdulmoneim AM et al., Saudi J Civ Eng, Mar, 2021; 5(2): 35-49

\begin{tabular}{|c|c|c|c|c|}
\hline Risk Group & Risk Code & $\begin{array}{l}\text { Risk Importance } \\
\text { Index RII \% }\end{array}$ & Ranking & $\begin{array}{l}\text { Risk Importance } \\
\text { Degree }\end{array}$ \\
\hline Group F & $\mathrm{F} 2$ & 35.69 & 30 & \\
\hline Group B & B4 & 35.67 & 31 & \\
\hline Group D & D8 & 35.6 & 32 & \\
\hline Group E & E1 & 35.5 & 33 & \\
\hline Group G & G7 & 35.41 & 34 & \\
\hline Group F & F3 & 34.93 & 35 & \\
\hline Group E & E7 & 34.87 & 36 & \\
\hline Group H & $\mathrm{H} 2$ & 34.8 & 37 & \\
\hline Group $\mathrm{G}$ & G4 & 34.72 & 38 & \\
\hline Group E & E3 & 34.57 & 39 & \\
\hline Group C & C1 & 34.33 & 40 & \\
\hline Group H & $\mathrm{H} 8$ & 34.29 & 41 & \\
\hline Group G & G1 & 33.74 & 42 & \\
\hline Group C & C3 & 33.65 & 43 & \\
\hline Group D & D4 & 33.64 & 44 & \\
\hline Group G & G10 & 33.26 & 45 & \\
\hline Group H & $\mathrm{H} 3$ & 33.24 & 46 & \\
\hline Group G & G11 & 32.01 & 47 & \\
\hline Group C & C6 & 31.68 & 48 & \\
\hline Group H & $\mathrm{H} 10$ & 31.45 & 49 & \\
\hline Group H & H5 & 31.45 & 50 & \\
\hline Group E & E5 & 30.59 & 51 & \\
\hline Group G & G6 & 30.57 & 52 & \\
\hline Group C & $\mathrm{C} 4$ & 30.27 & 53 & \\
\hline Group F & F4 & 29.72 & 54 & slightly important \\
\hline Group C & $\mathrm{C} 5$ & 25.08 & 55 & \\
\hline Group A & A-2 & 21.69 & 56 & \\
\hline Group A & A-3 & 21.56 & 57 & \\
\hline
\end{tabular}

\section{CONCLUSION}

In this research the author aim to put an add value to the mega project risks literature, and bring as much as possible of the risks which may impact negatively the mega projects in Saudi Arabia and prioritizing those identified risks according to its effect throughout the calculation of risk Importance Index RII depending on the mentioned equations \# 2, 3, \& 4 [27], the field survey was the supportive methodology to collect the date and the analyses it as following:

Risks were defined through the participation of experts in project management in different disciplines, where data collection techniques were used, and literature reviews were conducted to identify the most effective risks, and interviews were conducted with 30 experts in managing mega projects, and accordingly the risks under study were identified.

In this research the RBS built depending on 2 main category of risks which are the internal and External Risks internal means that the risk related to mega project itself and the external is related to the reasons surrounding it, and 8 submain risk categories, below that submain category the 57 risks identified which is compatible with Mega projects at Saudi Arabia refer to tables $4 \& 5$ and Figure \# 1
Creating a new group of risk factors related to the mega project's characteristics (risks group \# H) can be added to the literature of the mega project risks groups and considered under the internal risk Group.

The questionnaire was designed in order to determine the probability and impact of the identified risks, it was published to particular population, the data was collected from 78 participant from different experiences in managing the mega projects this number of participants is covering the sample size according to the equation \# 1 .

The ranking and prioritization for the identified risks done by the qualitative analysis which assets for the same as a part of risk analysis process, depending on the questionnaire participant respond, using their probability of occurring and the impact on project objectives if the risks occur.

The identified risks ranked depending on the risk severity and then the most significant 15 risks assigned 
Table-10 as the most severe risks for further quantitative analysis those 15 significant risks used to determine the contingency impact on the mega projects cost and time throughout the decision-making model (Recommended in the $2^{\text {nd }}$ part of the research).

The most severe risk was risk \# H6 which related to mega project characteristics group $(\mathrm{H})$ as it had the highest RII this risk trigger is the long duration and huge budget of the mega project.
It was expected to have a large severity in the risk group D (Technical Risk Group) due to the complexity and huge details of the mega project and it was a realistic result as we have 4 technical risks in the high ranking 15 risk list those risks was D5 with a rank number 5 risk \# D1 with rank number 8, D3 with a rank number 9 and D2 with rank number 12 .

Economic \& Financial Risk (B) had 3 of 4 identified risk also in the high ranking 15 risk list this is reflecting the importance of that risk group those significant risks was risk \# B2 this is the $2^{\text {nd }}$ significant risk, risk \# B3 it was the $3^{\text {rd }}$ and risk \# B1 was number 14.

Table-10: List or highest significant 15 Risks

\begin{tabular}{|c|c|c|c|c|}
\hline $\begin{array}{l}\text { Risk } \\
\text { Group }\end{array}$ & $\begin{array}{l}\text { Risk } \\
\text { Code }\end{array}$ & & Ranking & $\begin{array}{l}\text { Risk } \\
\text { Importance } \\
\text { Degree }\end{array}$ \\
\hline Group H & H6 & $\begin{array}{l}\text { Huge budget and very long duration give a chance of cost over run } \\
\text { and schedule slippage due to lack of cost and time management. }\end{array}$ & 1 & \multirow{15}{*}{ Important } \\
\hline Group B & $\mathbf{B 2}$ & $\begin{array}{l}\text { Incas of governmental Mega project, as a result of the economic } \\
\text { recession the government payment policy change or financing has } \\
\text { stalled }\end{array}$ & 2 & \\
\hline Group B & B3 & $\begin{array}{l}\text { Shortage of contractor cash out during the negative period of cash } \\
\text { flow when expenditures are higher than incoming payments }\end{array}$ & 3 & \\
\hline Group D & D5 & $\begin{array}{l}\text { Poor estimation of the project cost due to the project complexity } \\
\text { and huge size. }\end{array}$ & 4 & \\
\hline Group A & A4 & $\begin{array}{l}\text { Change of legal action related to the labor system and work which } \\
\text { may lead to Impose additional taxes on foreign labor }\end{array}$ & 5 & \\
\hline Group G & G8 & A lot of design changes during construction & 6 & \\
\hline Group $\mathrm{H}$ & H9 & $\begin{array}{l}\text { Unrealistic schedules and budgeting Due to inadequate project } \\
\text { plan. }\end{array}$ & 7 & \\
\hline Group D & D1 & $\begin{array}{l}\text { Inadequate project complexity analysis which leads to technical } \\
\text { problems starting from design phase }\end{array}$ & 8 & \\
\hline Group D & D3 & $\begin{array}{l}\text { Discrepancy between shop drawing and design drawing for the } \\
\text { same discipline and Miss coordination between structural, } \\
\text { architectural and MEP drawing. }\end{array}$ & 9 & \\
\hline Group E & E8 & Lack of construction martial due to delay of supplier payment & 10 & \\
\hline Group A & $\mathbf{A 5}$ & Administrative Corruption & 11 & \\
\hline Group D & D2 & Delay of Design Drawing and then Shop Drawing. & 12 & \\
\hline Group A & A1 & Very high cost of compensations due to megaproject requirements. & 13 & \\
\hline Group B & B1 & $\begin{array}{l}\text { Unanticipated inflation due to an instability of the economic } \\
\text { situation and Currency fluctuation during construction stage. }\end{array}$ & 14 & \\
\hline Group G & G5 & Low labor productivity due to poor supervision & 15 & \\
\hline
\end{tabular}

\section{REFERENCES}

1. Assaf, S. A., \& Al-Hejji, S. (2006). Causes of delay in large construction projects.

2. Zidane, Y. J. T., Johansen, A., \& Ekambaram, A. (2013). Megaprojects-Challenges and lessons learned. Procedia-Social and Behavioral Sciences, 74, 349-357.
3. The Saudi Gazette.

(2017) https://www.zawya.com/mena/en/story/Saudi_Arab ias_top_10_mega_projects_valued_at_92blnZAWYA20170307040801/. Retrieved from https://www.zawya.com/saudi-arabia/en/.

4. Altshuler, A. L. (2003). The changing politics of urban public investment. 
5. Dimitriou, H. (2014). What constitutes a "successful" mega transport project?

6. Adnan Haidar. (2011). Analysis and optimization of megaproject performance.

7. Ruuska, I. A. (2009). Dimensions of distance in a project network: Exploring Olkiluoto 3 nuclear power plant project. Int.

8. Flyvbjerg, B. B. (2003). Megaprojects and Risk: An Anatomy of Ambition.

9. Van Marrewijk, A. C. (2008). Managing publicprivate megaprojects.

10. Ilke Kardes a, A. O. (2013). Managing global megaprojects: Complexity and risk management.

11. Gellert, P. K. (2003). Mega-projects as displacements.

12. Prince Boateng, A, $\square$. Z. (2014). An Analytical Network Process model for risks prioritisation.

13. Merrow. (1988). Understanding the Outcomes of Megaprojects.

14. Miller, R. F. (2000). The Strategic Management of Large Engineering Projects.

15. Shore, B. (2005). Exploring the role of national culture in the management of large-scale international science projects. International Journal of Project Management.

16. Assaf, S. A., Al-Khalil, M., \& Al-Hazmi, M. (1995). Causes of delay in large building construction projects. Journal of management in engineering, 11(2), 45-50.

17. Al-Khalil, M. I., \& Al-Ghafly, M. A. (1999). Important causes of delay in public utility projects in Saudi Arabia. Construction Management \& Economics, 17(5), 647-655.

18. Al- Kharashi, A., \& Skitmore, M. (2009). Causes of delays in Saudi Arabian public sector construction projects. Construction Management and Economics, 27(1), 3-23.

19. Baghdadi, A., \& Kishk, M. (2015). Saudi Arabian aviation construction projects: Identification of risks and their consequences. Procedia Engineering, 123, 32-40.

20. Alotaibi, N., Sutrisna, M., \& Chong, H. (2015). Managing Critical Factors Causing Delays in Public Construction Projects in Kingdom of Saudi Arabia. In The 6th International Conference on Engineering, Project, and Production Management (EPPM2015) (pp. 109-117).

21. Elawi, G. S. A., Algahtany, M., \& Kashiwagi, D. (2016). Owners' perspective of factors contributing to project delay: case studies of road and bridge projects in Saudi Arabia. Procedia Engineering, 145, 1402-1409.

22. Mohammed, Algahtany, M.S. (2018). Identification and Assessment of Risks out of Contractors' Control in the Saudi Construction Industry.

23. Pieplow. (2012). Project Risk Management Handbook.

24. Hillson. (2002). Extending the risk Process to Manage Opportunities.

25. PMI. (2107). PMBOK guide.

26. COCHRAN. (1977). Sampling Techniques, 3rd edition. New York.

27. Kendall, M. A. (1990). Rank Corrlation Method Fifth Edition. Oxford University Press.

28. Al-Ghafly, M. (1999). Delay in public utility projects in.

29. Falqi, I. (2004). Delays in Project Completion: A comparative study of construction delay factors in Saudi Arabia and the United Kingdom. 